\title{
Sistem Pakar Mendiagnosa Kerusakan Handphone Oppo Dengan Menggunakan Teorema Bayes.
}

\author{
Saiful Nur Arif*, Muhammad Syahril **, Sri Kusnasari**, Hendryan Winata*** \\ * Program Studi Sistem Komputer, STMIK Triguna Dharma \\ **Program Studi Sistem Informasi, STMIK Triguna Dharma \\ ****Program Studi Sistem Informasi, STMIK Triguna Dharma
}

\begin{abstract}
Abstrak
Dalam konsep mendiagnosa kerusakan handphone ada berbagai sistem yang dapat diterapkan untuk mengatasi masalah ketidakpastian saat proses pemeriksaan terjadi. Salah satu sistem yang dapat digunakan adalah teorema bayes. Adanya ketidakpastian pada proses pemeriksaan dapat terjadi karena adanya perubahan pengetahuan yang ada di dalam sistem. Untuk itu diperlukan adanya suatu metode untuk mengatasi permasalahan tersebut. Dalam penelitian ini telah di terapkan suatu metode untuk mengatasi permasalahan tersebut. Dalam penelitian ini telah diterapkan suatu metode untuk mengatasi ketidakpastian dengan teorema bayes untuk mendiagnosa kerusakan handphone OPPO F5/F7/F9. Subjek pada penelitian ini adalah proses pemeriksaan handphone untuk menentukan kerusakan handphone dengan model penalaran dan metode kepastianya menggunakanan teorema bayes dengan cara menghitung nilai probabilitas suatu kerusakan handphone dan membandingkan probabilitas setiap gejalanya. Model pengembangan perangkat lunak yang digunakan dalam penelitian ini adalah Waterfall diawali dengan analisis data, perancangan sistem, pengkodean, dan pengujian sistem. Dari penelitian yang dilakukan menghasilkan sebuah perangkat lunak yaitu sistem yang mampu mendiagnosa kerusakan handphone OPPO F5/F7/F9 dengan menerapkan metode bayes. Hasil uji coba sistem ini menunjukan bahwa aplikasi ini layak dan dapat digunakan.
\end{abstract}

Kata kunci : Mendiagnosa kerusakan handphone oppo f5/f7/f9.

\section{Abstract}

In the concept of diagnosing damaged cellphones, there are various systems that can be applied to overcome the problem of uncertainty when the inspection process occurs. One of the systems that can be used is the Bayes theorem. The existence of uncertainty in the inspection process can occur due to changes in knowledge in the system. For that we need a method to overcome these problems. In this research, a method has been applied to overcome these problems. In this study, a method to overcome uncertainty with the Bayes theorem has been applied to diagnose damaged OPPO F5 / F7 / F9 cellphones. The subject in this study is the process of examining cellphones to determine damage to cellphones with a reasoning model and the method of certainty using the Bayes theorem by calculating the probability value of a cellphone damage and comparing the probability of each symptom. The software development model used in this research is Waterfall begins with data analysis, system design, coding, and system testing. From the research conducted, it produces a software that is a system that is able to diagnose damaged OPPO F5 / F7 / F9 cellphones by applying the Bayes method. The test results of this system show that this application is feasible and can be used.

Keywords: Diagnose damaged cellphone oppo f5 / f7 / f9.

\section{PENDAHULUAN}

Informasi dan teknologi dewasa ini menjadi hal yang sangat penting bagi kehidupan manusia. Untuk memenuhi kebutuhan hidup manusia secara cepat dan mudah, manusia membutuhkan informasi dan teknologi yang semakin canggih [1]. Handphone ( HP) adalah salah satu jenis dari media informasi dan 
teknologi yang sangat berkembang pesat saat ini. Handphone ( HP) adalah alat media komunikasi elektronik yang manfaatnya sama dengan telepon konvensional, akan tetapi handphone memiliki kelebihan mudah di bawa kemana - mana, mudah dalam penggunaaanya, serta didalam handphone dapat menyimpan fitur - fitur yang sangat canggih untuk berkomunikasi [2].

OPPO salah satunya Smartphone yang sedang booming di kalangan masyarakat. OPPO adalah penyedia layanan elektronik dan teknologi global yang membawakan perangkat elektronik seluler terbaru dan tercanggih di lebih dari 20 negara, seperti Australia, Eropa, Asia, Amerika Serikat, dan China. Keunggulan OPPO yaitu produsen yang bergerak ke arah pasar high-end namun memiliki harga yang cukup terjangkau, hampir seluruh smartphone bermerek OPPO memiliki baterai yang kuat atau tahan lama dengan melakukan pengisian selama 30 menit, selain itu hal yang menarik dari OPPO yaitu kualitas kameranya serta Layar oppo yang terkenal dengan resolusi tinggi dan berteknologi hal ini yang menyebabkan penggunanya betah memandangi layar smartphone yang jernih dan tajam [3].1

Theorema Bayes adalah metode yang terdapat pada Sistem Pakar, metode ini banyak digunakan untuk mencari solusi permasalahan yang berkaitan dengan probabilitas termasuk di dalamnya penerapan dalam pendeteksian masalah [5].

\section{METODE PENELITIAN}

\subsection{Kerusakan Handphone OPPO}

Masalah pada perangkat OPPO sangatlah bermacam-macam, mulai dari handphone tidak bisa di cas, insert SIM, mati total, LCD bergaris, layar tidak jelas, handphone restart sendiri, aplikasi telah berhenti, launcher telah berhenti, bila status telah berhenti, notifikasi tidak muncul, Bootloop atau gagal booting dan berhenti di logo, dan masalah - masalah lainnya yang masih banyak lagi[6]. Kerusakan handphone OPPO dipengaruhi oleh berbagai faktor seperti virus, bugs atau kerusakan pada aplikasi, file sampah yang tidak dibersihkan, dan lainnya. Saat ini pemeriksaan yang dapat mendiagnosa dengan pasti serta akurasi yang tinggi adalah pemeriksaan dengan menggunakan alat Fiber Microscope Optik Alat Pendeteksi, namun karena alat tersebut memiliki harga cukup mahal, sehingga jarang dimiliki oleh semua pengguna, kususnya di Negara kita.

Kerusakan handphone adalah perubahan apa pun dalam handphone yang menurun dari kondisi awalnya. Secara luas dapat didefinisikan sebagai perubahan yang di masukkaan ke dalam sistem yang memepengaruhi kinerja saat ini atau masa yang akan datang. Kerusakan tidak selalu berarti hilangnya total fungsi sistem, melainkan bahwa sistem tidak lagi beroprasi secara optimal. Kerusakan pada fisik handphone dapat terjadi akibat proses fisik progresif dengan handphone yang membuat handphone menjadi pecah dan termasuk tekanan mekanis yang melemahkan suatu struktur dalam handphone walaupun tekanan ini tidak terlihat. Umumnya seseorang akan menyadari bahwa handphone yang dimilikinya telah rusak ketika kondisi handphone tidak memungkinkan lagi untuk diperbaiki. Jadi untuk mengurangi resiko kerusakan pada handphone yang kita miliki, kita membutuhkan informasi lengkap saat pembelian dan memahami seluruh fungsioanal dalam handphone, serta mencai informasi di internet dan apabila ada masalah dalam penggunaan maka lakukanlah pemeriksaan pada konter handphone yang terpercaya. Dengan menjaga handphone yang baik maka aktivitas dan kinerja handphone menjadi lebih produktif .

\subsection{Sistem Pakar}

Sistem pakar (expert system) adalah sistem yang berusaha mengadopsi pengetahuan manusia ke komputer, agar komputer dapat menyelesaikan masalah seperti yang bisa di lakukan oleh para ahli. Sistem pakar yang baik di rancang agar dapat meyelesaikan permasalahan tertentu dengan meniru kerja dari pada ahli [7]. Beberapa pendapat para ahli mengenai sistem pakar. Menurut Budihartono dan Suhartono ( 2014 ), Sistem pakar adalah program komputer yang mensimulasi penilaian dan perilaku manusia atau organisasi yang memiliki pengetahuan dan pengalaman ahli dalam bidang tertentu. 
Sedangkan menurut Edward Feigenbaum ( 1982) mendefinisikan bahwa sistem pakar adalah suatu program komputer cerdas yang menggunkan knowledge ( pengetahuan) dan prosedur inferensi untuk menyelesaikan masalah yang cukup sulit sehingga membutuhkan seseorang ahli yang menyelsesaikanya[8]. Sistem pakar dilatarbelakangi oleh sebuah masalah dalam mencapai tujuan tertentu yaitu untuk membantu orang yang bukan pakar dalam menyelesaikan masalah yang terjadi. Menurut (suparman dan marlan 2007) sistem pakar terdiri dari dua komponen utama : Knowledge Base ( Basis Pengetahuan), Motor Interfensi dan user interface.

\subsection{Theorema Bayes}

Teorema Bayes adalah alogaritma yang menggunakan metode probabilitas dan statistik yang di temukan oleh seorang ilmuan Inggris Teorema Bayes. Yaitu memprediksi probabilitas di masa depan berdasarkan pengalaman di masa sebelumnya [15]. Metode Teorema Bayes ini memiliki beberapa kelebihan yaitu:

1. Bayes filter komputerisasi yang mudah.

2. Bayes memeriksa data secara keseluruhan.

3. Bayes fitering termasuk dalam supervised learning yaitu secara otomatis akan melakukan proses learning dari data yang masuk.

4. Bayes filtering cocok di terapkan di level aplikasi client atau individual user.

5. Bayes cocok diterapkan pada binary class yaitu klasifikasi ke dalam dua kelas.

Probailitas Bayes merupakan salah satu cara untuk mengatasi ketidapastian data dengan menggunakan formula Bayes yang dinayatakan:

1. Rumus probabilitas

$$
\mathrm{P}(\mathrm{H} \mid \mathrm{X})=\frac{\mathrm{P}(\mathrm{X} / \mathrm{H}) . \mathrm{P}(\mathrm{H}) \ldots \ldots \ldots(1)}{\mathrm{P}(\mathrm{X})}
$$

Dimana :

$\mathrm{P}(\mathrm{H} \mid \mathrm{X})$ : Probalilitas hipotesis $\mathrm{H}$ jika diberikan evidence $\mathrm{E}$.

$\mathrm{P}(\mathrm{X} \mid \mathrm{H})$ : Probabilitas munculnya evidence $\mathrm{E}$ jika di ketahui hipotesis $\mathrm{H}$.

$\mathrm{P}(\mathrm{H}) \quad$ : Probabilitas hipotesis $\mathrm{H}$ tanpa memandang evidence apapun.

$\mathrm{P}(\mathrm{X}) \quad$ : Probabilitas evidence $\mathrm{E}$.

2. Persamaan ini berasal dari teorema bayes

$$
\mathrm{P}\left(\mathrm{C}_{i} \mid \mathrm{X}\right)=\frac{\mathrm{P}\left(\mathrm{X} / \mathrm{C}_{i} \mid\right) . \mathrm{P}\left(\mathrm{C}_{i}\right) \ldots \ldots \ldots(2)}{\mathrm{P}(\mathrm{X})}
$$

Jika $\mathrm{P}(\mathrm{X})$ bernilai konstan maka semua kelasnya menjadi rumus

$\left.\mathrm{P}\left(\mathrm{C}_{i} \mid \mathrm{X}\right)\right)=\mathrm{P}\left(\mathrm{X} / \mathrm{C}_{i} \mid\right) . \mathrm{P}\left(\mathrm{C}_{i}\right)$

\subsection{Algoritma Sistem}

Alogaritma adalah urutan langkah - langkah logis tertentu untuk mencegah suatu masalah yang disusun secara berurutan untuk sebuah kegiatan atau instruksi. Serangkaian langkah - langkah atau urutan dalam logaritma memberikan instruki atau sebuah perintah keluaran yang diinginkan berdasarkan ide atau masukan yang di berikan.

Beberapa langkah - langkah atau tahapan yang dilakukan dalam pembuatan sistem yang akan di gunakan untuk meyelesaikan suatu masalah yaitu:

1. Menentukan data gejala kerusakan.

2. Menentukan nilai bobot dan nilai gejala.

3. Melakukan perhitungan Teorema Bayes

\subsubsection{Menentukan Data Kerusakan dan Gejala}

Sistem pakar adalah suatu sistem informasi yang berisi pengetahuan dari seorang pakar yang dapat kita gunakan untuk konsultasi. Pengetahuan seorang sistem pakar yang dimiliki oleh sistem pakar ini digunakan sebagai suatu dasar untuk meyelesaikan suatu pertanyaan atau menjawab pertanyaan.

Keberhasilan dari suatu sistem pakar ditentukan dari pengetahuan para ahli atau pakar yang di adopsi, dan bagaimana cara mengelola pengetahuan yang di peroleh dari wawancara tersebut kedalam sebuah tabel kerusakan handphone untuk memudahkan mendiagnosa keruskaan pada handphone OPPO F5/F7/F9

J-SISKO TECH Vol. 4, No. 1, Januari 2021: 112-126 
Pada tabel dibawah ini dapat dilihat gejala kerusakan handphone pada handphone OPPO F5/F7/F9.

Table 3.2 Gejala Kerusakan Handphone

\begin{tabular}{|c|c|c|}
\hline No. & Kode Gejala & Gejala Kerusakan \\
\hline 1. & G001 & $\begin{array}{l}\text { Saat mengaktifkan Bluetooth hp menjadi rusak atau macet } \\
\text { total }\end{array}$ \\
\hline 2. & G002 & Saat Bluetooth diaktifkan HP ter restart sendiri \\
\hline 3. & G003 & Bluetooth tidak bisa terhubung ke Bluetooth lain. \\
\hline 4. & G004 & Bluetoth tidak dapat dihidupkan \\
\hline 5. & G005 & Data tiba tiba hilang \\
\hline 6. & G006 & Tidak bisa diakses pada komputer atau laptop \\
\hline 7. & G007 & Tidak dapat membuka gallery pada HP \\
\hline 8. & G008 & HP bisa mengirim file tertentu saja \\
\hline 9. & G009 & HP hanya bisa menerima file tertentu saja \\
\hline 10. & G010 & Penekanan pada huruf menjadi acak \\
\hline 11. & G011 & Tulisan bergaris atau berantakan \\
\hline 12. & G012 & Sebagain tombol tidak berfungsi \\
\hline 13. & G013 & Sebagian tombol sulit ditekan \\
\hline 14. & G014 & Tidak ada reaksi ketika ditekan \\
\hline 15. & G015 & HP tiba tiba mati padahal isi baterai masih ada \\
\hline 16. & G016 & HP tidak penuh walaupun sudah diisi berjam jam \\
\hline 17. & G017 & Penggunaan baterai boros \\
\hline 18. & G018 & Tidak bisa dicarger \\
\hline 19. & G019 & Pada saat melakukan panggilan hp langsung mati \\
\hline 20 & G020 & Kinerja HP lambat dan tidak optimal \\
\hline 21 & G021 & HP tidak dapt booting ke menu \\
\hline 22 & G022 & Pemakaian HP sudah terlau lama \\
\hline 23 & G023 & HP Panas \\
\hline 24 & G024 & Mati Total \\
\hline 25 & G025 & LCD Bergaris \\
\hline 26 & G026 & Bercak hitam Pada LCD \\
\hline 27 & G027 & Lampu LCD Berkedap kedip \\
\hline 28 & 6028 & Layar tidak jelas \\
\hline 29 & G029 & LCD blank / mati \\
\hline
\end{tabular}

(Sumber:Konsultasi Dengan Bapak Nimrot Pandia)

\subsubsection{Menentukan Jenis Kerusakan Handphone}

Dari data gejala di atas dapat diklasifikasikan jenis kerusakan handphone . berikut merupakan jenis kerusakan handphone sebagai berikut:

3.3 Jenis Tingkatan Kerusakan Handphone

\begin{tabular}{|c|c|l|}
\hline No & Kode Kerusakan & \multicolumn{1}{|c|}{ Nama Kerusakan } \\
\hline 1. & K01 & Bluetooth \\
\hline 2. & K02 & Memory \\
\hline 3. & K03 & Keypad \\
\hline 4. & K05 & Baterai \\
\hline 5. & & IC Power \\
\hline
\end{tabular}




\begin{tabular}{|l|l|l|}
\hline 6. & K06 & LCD \\
\hline
\end{tabular}

(Sumber:Konsiltasi Dengan Bapak Nimrot Pandia)

\subsubsection{Menetukan Basis Pengetahuan}

\begin{tabular}{|c|c|c|c|c|c|c|c|c|}
\hline \multirow{3}{*}{ No. } & \multicolumn{8}{|c|}{ Table 3.4 Basis Pengetahuan Kerusakan Handphone } \\
\hline & \multirow{2}{*}{$\begin{array}{l}\text { KodeGej } \\
\text { ala }\end{array}$} & \multirow{2}{*}{ Gejala Kerusakan } & \multicolumn{6}{|c|}{ Kode Kerusakan } \\
\hline & & & K01 & K02 & K03 & K04 & K05 & K06 \\
\hline 1. & G001 & $\begin{array}{l}\text { Saat mengaktifkan } \\
\text { Bluetooth hp menjadi } \\
\text { rusak atau macet total }\end{array}$ & $\checkmark$ & & & & & \\
\hline 2. & G002 & $\begin{array}{c}\text { Saat Bluetooth } \\
\text { diaktifkan HP ter restart } \\
\text { sendiri }\end{array}$ & $\checkmark$ & & & & & \\
\hline 3. & G003 & $\begin{array}{l}\text { Bluetooth tidak bisa } \\
\text { terhubung ke Bluetooth } \\
\text { lain. }\end{array}$ & $\checkmark$ & & & & & \\
\hline 4. & G004 & $\begin{array}{l}\text { Bluetoth tidak dapat } \\
\text { dihidupkan }\end{array}$ & $\checkmark$ & & & & & \\
\hline 5. & G005 & Data tiba tiba hilang & & $\checkmark$ & & & & \\
\hline 6. & G006 & $\begin{array}{l}\text { Tidak bisa diakses pada } \\
\text { komputer atau laptop }\end{array}$ & & $\checkmark$ & & & & \\
\hline 7. & G007 & $\begin{array}{l}\text { Tidak dapat membuka } \\
\text { gallery pada HP }\end{array}$ & & $\checkmark$ & & & & \\
\hline 8. & G008 & $\begin{array}{l}\text { HP bisa mengirim file } \\
\text { tertentu saja }\end{array}$ & & $\checkmark$ & & & & \\
\hline 9. & G009 & $\begin{array}{c}\text { HP hanya bisa } \\
\text { menerima file tertentu } \\
\text { saja }\end{array}$ & & $\checkmark$ & & & & \\
\hline 10. & G010 & $\begin{array}{c}\text { Penekanan pada huruf } \\
\text { menjadi acak }\end{array}$ & & & $\checkmark$ & & & \\
\hline 11. & G011 & $\begin{array}{l}\text { Tulisan bergaris atau } \\
\text { berantakan }\end{array}$ & & & $\checkmark$ & & & \\
\hline 12. & G012 & $\begin{array}{l}\text { Sebagain tombol tidak } \\
\text { berfungsi }\end{array}$ & & & $\checkmark$ & & & \\
\hline 13. & G013 & $\begin{array}{l}\text { Sebagian tombol sulit } \\
\text { ditekan }\end{array}$ & & & $\checkmark$ & & & \\
\hline 14. & G014 & $\begin{array}{c}\text { Tidak ada reaksi ketika } \\
\text { ditekan }\end{array}$ & & & $\checkmark$ & & & \\
\hline 15. & G015 & $\begin{array}{c}\text { HP tiba tiba mati } \\
\text { padahal isi baterai } \\
\text { masih ada }\end{array}$ & & & & $\checkmark$ & & \\
\hline 16. & G016 & $\begin{array}{l}\text { HP tidak penuh } \\
\text { walaupun sudah diisi } \\
\text { berjam jam }\end{array}$ & & & & $\checkmark$ & & \\
\hline 17. & G017 & $\begin{array}{l}\text { Penggunaan baterai } \\
\text { boros }\end{array}$ & & & & $\checkmark$ & & \\
\hline 18. & G018 & Tidak bisa dicarger & & & & & $\checkmark$ & \\
\hline 19. & G019 & $\begin{array}{c}\text { Pada saat melakukan } \\
\text { panggilan hp langsung } \\
\text { mati }\end{array}$ & & & & & $\checkmark$ & \\
\hline 20. & G020 & $\begin{array}{c}\text { Kinerja HP lambat dan } \\
\text { tidak optimal }\end{array}$ & & & & & $\checkmark$ & \\
\hline
\end{tabular}




\begin{tabular}{|c|c|c|l|l|l|l|l|c|}
\hline 21. & G021 & $\begin{array}{c}\text { HP tidak dapt booting } \\
\text { ke menu }\end{array}$ & & & & & $\checkmark$ & \\
\hline 22. & G022 & $\begin{array}{c}\text { Pemakaian HP sudah } \\
\text { terlau lama }\end{array}$ & & & & & $\checkmark$ & \\
\hline 23. & G023 & HP Panas & & & & & $\checkmark$ & \\
\hline 24. & G024 & Mati Total & & & & & $\checkmark$ & \\
\hline 25. & G025 & LCD Bergaris & & & & & & $\checkmark$ \\
\hline 26. & G026 & $\begin{array}{c}\text { Bercak hitam Pada } \\
\text { LCD }\end{array}$ & & & & & & $\checkmark$ \\
\hline 27. & G027 & $\begin{array}{c}\text { Lampu LCD Berkedap } \\
\text { kedip }\end{array}$ & & & & & & $\checkmark$ \\
\hline 28. & G028 & Layar tidak jelas & & & & & & $\checkmark$ \\
\hline 29. & G029 & LCD blank / mati & & & & & & $\checkmark$ \\
\hline
\end{tabular}

Adapun identifikasi jenis kerusakan handphone sesuai dengan gejala di buat dalam bentuk Tabel 3.4 di atas.

Tabel 3.5 Solusi Kerusakan Handphone

\begin{tabular}{|c|c|c|}
\hline Kerusakan & Gejala Kerusakan & Solusi \\
\hline Bluetooth & 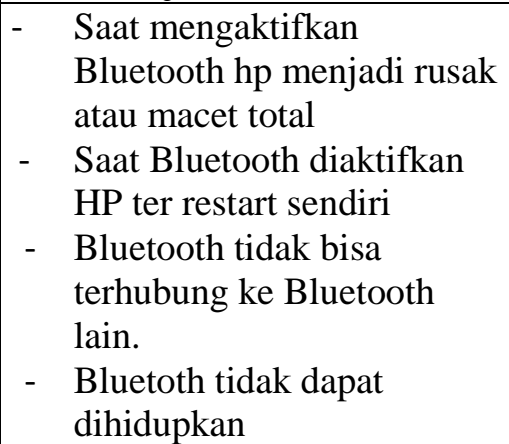 & $\begin{array}{l}\text { Gunakan aplikasi Bluetooth Fix Repair. } \\
\text { Aplikasi ini akan memperbaiki sistem } \\
\text { Bluetooth yang error pada Smartphone. } \\
\text { Cara kedua juga bisa anda lakukan } \\
\text { dengan cara Factory Reset. Fungsi dari } \\
\text { factory reset adalah mengembalikan dan } \\
\text { memperbaiki sistem android yang rusak. } \\
\text { Sebelum anda melakukan factory reset } \\
\text { anda perlu melakukan back up data dan } \\
\text { file android seperti dokumen atau game } \\
\text { anda agar nantinya tidak terhapus. }\end{array}$ \\
\hline Memory & $\begin{array}{ll}\text { - } & \text { Data tiba-tiba hilang } \\
\text { - } & \text { Tidak bisa diakses pada } \\
& \text { komputer atau laptop } \\
\text { - } & \text { Tidak dapt membuka } \\
& \text { gallery pada HP } \\
\text { - } \quad \text { HP bisa mengirim file } \\
\text { tertentu saja } \\
\text { - HP hanya bisa menerima } \\
\text { file tertentu saja }\end{array}$ & $\begin{array}{l}\text { Bersihkan lempengan tembaga kuning } \\
\text { yang berfungsi sebagai konektor dengan } \\
\text { penghapusan. Gosok perlahan dengan } \\
\text { bersih. Jika memory masih juga eror. } \\
\text { Silahkan anda format memory dengan } \\
\text { cara pergi ke menu Settings > Storage > } \\
\text { Portable storage dan pilih drive kartu SD } \\
\text { kamu. Pilih menu Storage settings > } \\
\text { Format > Earse \& Format. Tunggu } \\
\text { hingga proses selesai dan pilih Done. }\end{array}$ \\
\hline Keypad & 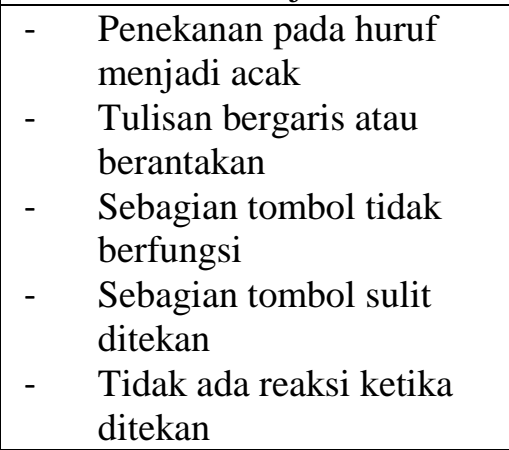 & $\begin{array}{l}\text { Pertama, masuk pada menu } \\
\text { "Setting", kemudian pilih "Aplikasi". } \\
\text { Lalu cari aplikasi keyboard yang anda } \\
\text { gunakan misalnya "Keyboard Android", } \\
\text { Kemudian "Hapus Data" dan "Hapus } \\
\text { Cache" aplikasi keybard tersebut. }\end{array}$ \\
\hline Baterai & $\begin{array}{l}\text { - } \quad \text { HP tiba-tiba mati padahal } \\
\text { isi baterai masih ada }\end{array}$ & $\begin{array}{l}\text { Masukkan baterai tersebut kedalam } \\
\text { plastic dan simpanlah di dalam freezer }\end{array}$ \\
\hline
\end{tabular}




\begin{tabular}{|c|c|c|}
\hline & $\begin{array}{ll}\text { - } & \text { HP tidak penuh walaupun } \\
\text { sudah diisi berjam-jam } \\
\text { - } & \text { Penggunaan baterai boros }\end{array}$ & $\begin{array}{l}\text { lemari es. Biarkan selama } 24 \text { jam } \\
\text { kemudian lihat hasilnya. Pastikan bagian } \\
\text { yang berwarna kuning bersih dari air. } \\
\text { Lalu coba lakukan pengisian daya selama } \\
2 \text { sampai } 3 \text { jam atau sampai baterai hp } \\
\text { penuh. Pasangkan baterai ke dalam } \\
\text { handphone. Jika baterai masih rusak } \\
\text { Solusinya adalah dengan cara membeli } \\
\text { baterai baru. Pastikan baterai yang dibeli } \\
\text { merupakkan baterai original agar lebih } \\
\text { awet dan terhindar dari kerusakaan yang } \\
\text { tidak diinginkan. }\end{array}$ \\
\hline IC power & $\begin{array}{ll}- & \text { Tidak bisa dicarger } \\
- & \text { Pada saat melakukan } \\
\text { panggilan hp langsung } \\
\text { mati } \\
\text { - } & \text { Kinerja HP lambat dan } \\
\text { tidak optimal } \\
\text { - } & \text { HP tidak dapat booting ke } \\
\text { menu } \\
\text { - } & \text { Pemakain HP sudah } \\
\text { - } & \text { terlau lama } \\
\text { - } & \text { HP panas } \\
& \text { Mati total }\end{array}$ & $\begin{array}{l}\text { Tekan ic power dengan jari kemudian } \\
\text { nyalakan, jika hidup lakukan rehot ic } \\
\text { power. Dan hindari penggunaan } \\
\text { handphone saat pengisian daya baterai. } \\
\text { Jika ic power juga masih tidak berfungsi } \\
\text { segera anda bawa ke teknisi handphone } \\
\text { atau counter handphone. }\end{array}$ \\
\hline LCD & $\begin{array}{ll}- & \text { LCD bergaris } \\
\text { - } & \text { Bercak hitam Pada LCD } \\
\text { - } & \text { Lampu LCD berkedap- } \\
& \text { kedip } \\
\text { - } & \text { Layar tidak jelas } \\
\text { - } & \text { LCD blank / mati }\end{array}$ & $\begin{array}{l}\text { Bersihkan kotoran atau karat yang } \\
\text { melekat pada LCD ponsel, lalu lakukan } \\
\text { resolder atau solder ulang driver LCD. } \\
\text { Jika LCD tidak dapat berfungsi dengan } \\
\text { baik maka silahkan ganti LCD. }\end{array}$ \\
\hline
\end{tabular}

(Sumber:Konsultasi Dengan Bapak Nimrot Pandia)

Tabel 3.6 Nilai Kepastian

\begin{tabular}{|c|l|}
\hline Kode Kerusakan & \multicolumn{1}{|c|}{ Level } \\
\hline K01 & Bluetooth \\
\hline K02 & Memory \\
\hline K03 & Keypad \\
\hline K04 & Baterai \\
\hline K05 & IC Power \\
\hline K06 & LCD \\
\hline
\end{tabular}

\subsubsection{Menentukan Nilai Probabilitas}

Dibawah ini merupakan tabel nilai dari gejala-gejala kerusakan handphone OPPO F5/F7/F9 yang didapat dari data pelanggan yang mengalami suatu kerusakaan handphone OPPO F5/F7/F9 yang telah melakukan konsultasi, dimana data terebut akan digunakan untuk mencari nilai probabilitas atau nilai gejala sebagai nilai untuk mendapatkan nilai kesimpulan bayes. Adapun nilai probabilitas dari gejala kerusakaan handphpone OPPO F5/F7/F9 adalah sebagai berikut:

Dari 29 contoh yang memiliki kerusakan handphone OPPO F5/F7/F9 maka Nilai Probabilitas didapat dari jumlah gejala sebagai total kerusakan. 
a. $\quad \mathrm{K} 01=$ Bluetooth

$$
\text { Rumus : } k(A \mid B)=\frac{K(B \cap A)}{K(\mathrm{~B})}
$$

Dari tabel data gejala untuk kerusakan Bluetooth yaitu 4 data maka:

$$
\begin{gathered}
\mathrm{G} 1=\frac{2}{4}=0.5 \\
\mathrm{G} 2=\frac{2}{4}=0.5 \\
\mathrm{G} 3=\frac{1}{4}=0.25 \\
\mathrm{G} 4=\frac{2}{4}=0.5
\end{gathered}
$$

b. $\mathrm{K} 02$ = Memori

Dari tabel data gejala untuk kerusakan Memori yaitu 5 data maka :

$$
\begin{aligned}
\mathrm{G} 5 & =\frac{3}{5}=0.6 \\
\mathrm{G} 6 & =\frac{3}{5}=0.6 \\
\mathrm{G} 7 & =\frac{2}{5}=0.4 \\
\mathrm{G} 8 & =\frac{3}{5}=0.6 \\
\mathrm{G} 9 & =\frac{2}{5}=0.4
\end{aligned}
$$

c. $\quad \mathrm{K} 03=$ Keypad

Dari tabel data gejala untuk kerusakan Keyped yaitu 5 data maka :

$$
\begin{aligned}
& \mathrm{G} 10=\frac{3}{5}=0.6 \\
& \mathrm{G} 11=\frac{2}{5}=0.4
\end{aligned}
$$

$\mathrm{G} 12=\frac{3}{5}=0.6$

$\mathrm{G} 13=\frac{2}{5}=0.4$

$\mathrm{G} 14=\frac{2}{5}=0.4$

d. $\mathrm{K} 04=$ Baterai

Dari tabel data gejala untuk kerusakan Baterai yaitu 4 data maka:

$\begin{aligned} \mathrm{G} 15 & =\frac{2}{3}=0.66 \\ \mathrm{G} 16 & =\frac{1}{3}=0.33 \\ \mathrm{G} 17= & \frac{1}{3}=0.33 \\ \text { e. } \mathrm{K} 05 & =\text { IC Power }\end{aligned}$

Dari tabel data gejala untuk kerusakan IC Power yaitu 7 data maka :
$\mathrm{G} 18=\frac{3}{7}=0.42$
$\mathrm{G} 19=\frac{4}{7}=0.57$
$\mathrm{G} 20=\frac{5}{7}=0.71$
$\mathrm{G} 21=\frac{4}{7}=0.57$
$\mathrm{G} 22=\frac{2}{7}=0.28$
$\mathrm{G} 23=\frac{4}{7}=0.57$
$\mathrm{G} 24=\frac{4}{7}=0.57$

f. $\quad \mathrm{K} 06=\mathrm{LCD}$

Dari tabel data gejala untuk kerusakan LCD yaitu 5 data maka :
$\mathrm{G} 25=\quad \frac{3}{5}=0.6$
$\mathrm{G} 26=\quad \frac{2}{5}=0.4$
$\mathrm{G} 27=\frac{3}{5}=0.6$
$\mathrm{G} 28=\frac{3}{5}=0.6$ 
$\mathrm{G} 29=\frac{2}{5}=0.4$

Dari proses perhitungan diatas maka didapat nilai probabilitas setiap gejala berdasarkan jenis kerusakan. Berikut adalah tabel nilai probabilitas setiap gejala

Tabel 3.8 Nilai Probabilitas

\begin{tabular}{|c|c|c|c|c|}
\hline $\begin{array}{c}\text { Kode } \\
\text { Kerusakan }\end{array}$ & $\begin{array}{c}\text { Nama } \\
\text { Kerusakan }\end{array}$ & $\begin{array}{c}\text { Kode } \\
\text { Gejala }\end{array}$ & Gejala kerusakan & Probabilitas \\
\hline \multirow[t]{4}{*}{ K01 } & \multirow[t]{4}{*}{ Bluetooth } & G001 & $\begin{array}{l}\text { Saat mengaktifkan } \\
\text { Bluetooth hp menjadi } \\
\text { rusak atau macet total }\end{array}$ & 0.5 \\
\hline & & G002 & $\begin{array}{l}\text { Saat Bluetooth } \\
\text { diaktifkan HP ter } \\
\text { restart sendiri }\end{array}$ & 0.5 \\
\hline & & G003 & $\begin{array}{l}\text { Bluetooth tidak bisa } \\
\text { terhubung ke } \\
\text { Bluetooth lain. }\end{array}$ & 0.25 \\
\hline & & G004 & $\begin{array}{l}\text { Bluetoth tidak dapat } \\
\text { dihidupkan }\end{array}$ & 0.5 \\
\hline \multirow[t]{5}{*}{ K02 } & \multirow[t]{5}{*}{ Memori } & G005 & Data tiba tiba hilang & 0.6 \\
\hline & & G006 & $\begin{array}{c}\text { Tidak bisa diakses } \\
\text { pada komputer atau } \\
\text { laptop }\end{array}$ & 0.6 \\
\hline & & G007 & $\begin{array}{c}\text { Tidak dapat } \\
\text { membuka gallery } \\
\text { pada HP }\end{array}$ & 0.4 \\
\hline & & G008 & $\begin{array}{l}\text { HP bisa mengirim } \\
\text { file tertentu saja }\end{array}$ & 0.6 \\
\hline & & G009 & $\begin{array}{c}\text { HP hanya bisa } \\
\text { menerima file } \\
\text { tertentu saja }\end{array}$ & 0.4 \\
\hline \multirow[t]{5}{*}{ K03 } & \multirow[t]{5}{*}{ Keypad } & G010 & $\begin{array}{l}\text { Penekanan pada } \\
\text { huruf menjadi acak }\end{array}$ & 0.6 \\
\hline & & G011 & $\begin{array}{l}\text { Tulisan bergaris atau } \\
\text { berantakan }\end{array}$ & 0.4 \\
\hline & & G012 & $\begin{array}{l}\text { Sebagain tombol } \\
\text { tidak berfungsi }\end{array}$ & 0.6 \\
\hline & & G013 & $\begin{array}{l}\text { Sebagian tombol sulit } \\
\text { ditekan }\end{array}$ & 0.4 \\
\hline & & G014 & $\begin{array}{l}\text { Tidak ada reaksi } \\
\text { ketika ditekan }\end{array}$ & 0.4 \\
\hline \multirow[t]{3}{*}{ K04 } & \multirow[t]{3}{*}{ Baterai } & G015 & $\begin{array}{l}\text { HP tiba tiba mati } \\
\text { padahal isi baterai } \\
\text { masih ada }\end{array}$ & 0.66 \\
\hline & & G016 & $\begin{array}{l}\text { HP tidak penuh } \\
\text { walaupun sudah diisi } \\
\text { berjam jam }\end{array}$ & 0.33 \\
\hline & & G017 & $\begin{array}{l}\text { Penggunaan baterai } \\
\text { boros }\end{array}$ & 0.33 \\
\hline \multirow[t]{3}{*}{ K05 } & \multirow[t]{3}{*}{ IC Power } & G018 & Tidak bisa dicarger & 0.42 \\
\hline & & G019 & $\begin{array}{l}\text { Pada saat melakukan } \\
\text { panggilan hp } \\
\text { langsung mati }\end{array}$ & 0.57 \\
\hline & & G020 & $\begin{array}{l}\text { Kinerja HP lambat } \\
\text { dan tidak optimal }\end{array}$ & 0.71 \\
\hline
\end{tabular}




\begin{tabular}{|l|l|l|l|l|}
\hline \multirow{2}{*}{} & \multirow{2}{*}{} & G021 & $\begin{array}{l}\text { HP tidak dapt } \\
\text { booting ke menu }\end{array}$ & 0.57 \\
\cline { 3 - 5 } & & G022 & $\begin{array}{l}\text { Pemakaian HP sudah } \\
\text { terlau lama }\end{array}$ & 0.28 \\
\cline { 3 - 5 } & & G023 & HP Panas & 0.57 \\
\hline & LCD & G024 & Mati Total & 0.57 \\
\hline \multirow{2}{*}{ K06 } & & G025 & LCD Bergaris & 0.6 \\
\cline { 3 - 5 } & & G026 & $\begin{array}{l}\text { Bercak hitam Pada } \\
\text { LCD }\end{array}$ & 0.4 \\
\cline { 3 - 5 } & & G027 & $\begin{array}{l}\text { Lampu LCD } \\
\text { Berkedap kedip }\end{array}$ & 0.6 \\
\cline { 3 - 5 } & & Layar tidak jelas & 0.6 \\
\cline { 3 - 5 } & & 6028 & LCD blank / mati & 0.4 \\
\cline { 3 - 5 } & G029 & & \\
\hline
\end{tabular}

\subsubsection{Proses Perhitungan Metode Teorema Bayes}

Berikut ini merupakan kasus yang menunjukan adanya suatu gejala dari kerusakan Handphone.

Seorang pelanggan pada kerusakan handphone mengalami gejala dari memiliki gejala dari kerusakan handphone kemudian pelangan melakukan suatu konsultasi kepada ahli teksini yang bernama Nimrot Pandia. dari 20 pilihan gejala yang akan diberikan kepada pelanggan dengan jawaban sebagai berikut:

\begin{tabular}{|c|l|c|}
\multicolumn{5}{|c|}{ Tabel 3.9 Konsultasi } \\
\hline Kode Gejala & \multicolumn{1}{|c|}{ Pertanyaan Berdasarkan Gejala } & Jawaban \\
\hline G001 & $\begin{array}{l}\text { Saat mengaktifkan Bluetooth hp menjadi rusak } \\
\text { atau macet total }\end{array}$ & TIDAK \\
\hline G002 & Saat Bluetooth diaktifkan HP ter restart sendiri & IYA \\
\hline G003 & Bluetooth tidak bisa terhubung ke Bluetooth lain & TIDAK \\
\hline G004 & Bluetoth tidak dapat dihidupkan & TIDAK \\
\hline G005 & Data tiba tiba hilang & TIDAK \\
\hline G006 & Tidak bisa diakses pada komputer atau laptop & IYA \\
\hline G007 & Tidak dapat membuka gallery pada HP & TIDAK \\
\hline G008 & HP bisa mengirim file tertentu saja & TIDAK \\
\hline G009 & HP hanya bisa menerima file tertentu saja & TIDAK \\
\hline G010 & Penekanan pada huruf menjadi acak & IYA \\
\hline G011 & Tulisan bergaris atau berantakan & TIDAK \\
\hline G012 & Sebagain tombol tidak berfungsi & TIDAK \\
\hline G013 & Sebagian tombol sulit ditekan & TIDAK \\
\hline G014 & Tidak ada reaksi ketika ditekan & TIDAK \\
\hline G015 & HP tiba tiba mati padahal isi baterai masih ada & TIDAK \\
\hline G016 & HP tidak penuh walaupun sudah diisi berjam jam & IYA \\
\hline G017 & Penggunaan baterai boros & TIDAK \\
\hline G018 & Tidak bisa dicarger & IYA \\
\hline G019 & Pada saat melakukan panggilan hp langsung mati & TIDAK \\
\hline G020 & Kinerja HP lambat dan tidak optimal & TIDAK \\
\hline G021 & HP tidak dapt booting ke menu & TIDAK \\
\hline G022 & Pemakaian HP sudah terlau lama & TIDAK \\
\hline G023 & HP Panas & IYA \\
\hline G024 & Mati Total & TIDAK \\
\hline G025 & LCD Bergaris & IYA \\
\hline G026 & Bercak hitam Pada LCD & IYA \\
\hline G027 & Lampu LCD Berkedap kedip & \\
\hline & & \\
\hline
\end{tabular}




\begin{tabular}{|l|l|c|}
\hline 6028 & Layar tidak jelas & IYA \\
\hline G029 & LCD blank / mati & IYA \\
\hline
\end{tabular}

(Sumber:Konsultasi Dengan Bapak Nimrot Pandia)

Untuk melakukan suatu perhitungan dalam memastikan kerusakan pada handphone OPPO F5/F7/F9 maka di perlukan suatu perhitungan sebagai berikut :

1. Dengan nilai probabilitas yang sudah ditentukan maka selanjutnya akan dijumlahkan nilai probabilitas tersebut. Berdasarkan data sampel baru yang bersumber dari tabel konsultasi.

a.K01 = Bluetooth

$$
=\sum_{G n}^{n} k=1=G n+\cdots+G n
$$

$$
\mathrm{G} 2=\mathrm{K}(\mathrm{E} \mid \mathrm{H} 1)=0.5
$$

$$
=\sum_{G=1}^{1} k=1=0.5
$$

b. $\mathrm{K} 02=$ Memori

$$
\mathrm{G} 6=\mathrm{K}(\mathrm{E} \mid \mathrm{H} 6)=0.6
$$

$$
=\sum_{G=1}^{1} k=1=0.6
$$

c. $\mathrm{K} 03=\mathrm{Keypad}$

$\mathrm{G} 10=\mathrm{K}(\mathrm{E} \mid \mathrm{H} 10)=0.6$

$$
=\sum_{G=1}^{1} K=1=0.6
$$

d. $\mathrm{K} 04=$ Baterai

$\mathrm{G} 16=\mathrm{K}(\mathrm{E} \mid \mathrm{H} 16)=0.33$

$$
=\sum_{G=1}^{1} k=1=0.33
$$

e. K05= IC Power

$\mathrm{G} 18=\mathrm{K}(\mathrm{E} \mid \mathrm{H} 18)=0.42$

$$
\mathrm{G} 23=\mathrm{K}(\mathrm{E} \mid \mathrm{H} 23) \quad=0.57
$$

$$
=\sum_{k=2}^{2} K=2=0.42+0.57=0.99
$$

f. $\mathrm{K} 06=\mathrm{LCD}$

$$
\begin{array}{lc}
\mathrm{G} 25=\mathrm{K}(\mathrm{E} \mid \mathrm{H} 25) & =0.6 \\
\mathrm{G} 27=\mathrm{K}(\mathrm{E} \mid \mathrm{H} 27) & =0.6 \\
\mathrm{G} 28=\mathrm{K}(\mathrm{E} \mid \mathrm{H} 28) & =0.6 \\
\mathrm{G} 29=\mathrm{K}(\mathrm{E} \mid \mathrm{H} 2) & =0.4 \\
& =\sum_{G=4}^{4} k=4=0.6+0.6+0.6+0.4=2.2
\end{array}
$$

2. Selanjutnya mencari suatu Probabilitas hipotesa $H$ tanpa memandang evidence dengan cara membagikan nilai probabilitas evidence awal dengan hasil penjumlahan probabilitas berdasarkan suatu data sempel baru.

$$
\begin{aligned}
& \text { a.K01 = Bluetooth } \\
& \mathrm{G} 2=\mathrm{K}(\mathrm{H} 1) \quad=\frac{0.5}{0.5}=1
\end{aligned}
$$$$
k(H i)=\frac{\mathrm{k}(\mathrm{E} \mid \mathrm{Hi})}{\sum_{k}^{n}=n}
$$ 
b. $\mathrm{K} 02=$ Memori

$\mathrm{G} 6=\mathrm{K}(\mathrm{H} 6)=\frac{0.6}{0.6}=1$

c.K03 = Keyped

$\mathrm{G} 10=\mathrm{K}(\mathrm{H} 10)=\frac{0.6}{0.6}=1$

d. $\mathrm{K} 04=$ Baterai

$$
\mathrm{G} 16=\mathrm{K}(\mathrm{H} 16)=\frac{0.33}{0.33}=1
$$

e.K05= IC Power

$$
\begin{aligned}
& \mathrm{G} 18=\mathrm{K}(\mathrm{H} 18)=\frac{0.42}{0.99}=0.42 \\
& \mathrm{G} 23=\mathrm{K}(\mathrm{H} 23)=\frac{0.58}{0.99}=0.58
\end{aligned}
$$

f. $\quad \mathrm{K} 06=\mathrm{LCD}$

$$
\begin{aligned}
& \mathrm{G} 25=\mathrm{K}(\mathrm{H} 25)=\frac{0.6}{2.2}=0.27 \\
& \mathrm{G} 27=\mathrm{K}(\mathrm{H} 27)=\frac{0.6}{2.2}=0.27 \\
& \mathrm{G} 28=\mathrm{K}(\mathrm{H} 28)=\frac{0.6}{2.2}=0.27 \\
& \mathrm{G} 29=\mathrm{K}(\mathrm{H} 27)=\frac{0.4}{2.2}=0.18
\end{aligned}
$$

2. Langkah selanjutnya mencari probabilitas hipotesis memandang evidence dengan suatu cara mengalikan nilai probabilitas evidence dan menjumlahkan hasil perkalian bagi masing-masing hipotesis.

a. $\quad \mathrm{K} 01=$ Bluetooth

$$
=\sum_{k=n}^{n}=k\left(H_{\mathrm{i}}\right) * k\left(E \mid H_{\mathrm{i}}\right)+\cdots+K\left(H_{\mathrm{i}}\right) * K\left(E \mid H_{\mathrm{i}}\right)
$$

$$
\sum_{\substack{k=1 \\=0.5}}^{1}=(0.5 * 1)
$$

b. $\mathrm{K} 02=$ Memori

$$
\sum_{\substack{k=1 \\=0.6}}^{1}(0.6 * 1)
$$

c.K03 = Keyped

$$
\sum_{\substack{k=1 \\=0.6}}^{1}(0.6 * 1)
$$

d. $\mathrm{K} 04=$ Baterai

$$
\begin{gathered}
\sum_{k=1}^{1}=(0.33 * 1) \\
=0.33
\end{gathered}
$$

e. $\mathrm{K} 05=\mathrm{IC}$ Power

$$
\begin{aligned}
\sum_{k=2}^{2} & =(0.42 * 0.42)+(0.57 * 0.58) \\
& =0.176+0.33 \\
& =0.51
\end{aligned}
$$


f. $\mathrm{K} 06=\mathrm{LCD}$

$$
\begin{aligned}
\sum_{k=4}^{4}= & (0.6 * 0.272)+(0.6 * 0.272)+(0.6 * 0.272)+(0.4 * 0.181) \\
& =0.163+0.163+0.163+0.072 \\
& =0.56
\end{aligned}
$$

3. Selanjutnya mencari nilai $\mathrm{k}\left(\mathrm{H}_{\mathrm{i}} \mid \mathrm{E}_{\mathrm{i}}\right)$ atau probabilitas hipotesis $\mathrm{H}$, dengan suatu cara menghasilkan hasil nilai dari probabilitas hipotesa tanpa memandang suatu evidence dengan suatu nilai probabilitas awal lalu dibagi hasil probabilitas hipotesa dengan memandang evidence.

a. $\quad \mathrm{K} 01=$ Bluetooth

$$
k\left(H_{\mathrm{i}} \backslash E_{\mathrm{i}}\right)=\frac{K\left(H_{\mathrm{i}}\right) * K\left(E \backslash H_{\mathrm{i}}\right)}{\sum_{k}^{n}=N}
$$

$$
\mathrm{K}(\mathrm{H} 2 \mathrm{E})=\frac{1 * 0.5}{0.5} \quad=1
$$

b. $\mathrm{K} 02=$ Memori

$$
\mathrm{K}(\mathrm{H} 6 \mathrm{~V})=\frac{1 * 0.6}{0.6}=1
$$

c. $\mathrm{K} 03=$ Keyped

$$
\mathrm{K}(\mathrm{H} 10 \mathrm{lE})=\frac{1 * 0.6}{0.6}=1
$$

d. $\mathrm{K} 04=$ Baterai

$$
\mathrm{K}(\mathrm{H} 16 \mathrm{VE})=\frac{1 * 0.33}{0.33}=1
$$

e. $\mathrm{K} 05=\mathrm{IC}$ Power

$$
\begin{aligned}
& \mathrm{K}(\mathrm{H} 18 \backslash \mathrm{E})=\frac{0.42 * 0.42}{0.51}=0.34 \\
& \mathrm{~K}(\mathrm{H} 23 \backslash \mathrm{E})=\frac{0.58 * 0.58}{0.51}=0.65
\end{aligned}
$$

f. $\mathrm{K} 06=\mathrm{LCD}$

$$
\begin{aligned}
& \mathrm{K}(\mathrm{H} 25 \backslash \mathrm{E})=\frac{0.27 * 0.6}{0.56}=0.28 \\
& \mathrm{~K}(\mathrm{H} 27 \mathrm{E})=\frac{0.27 * 0.6}{0.56}=0.28 \\
& \mathrm{~K}(\mathrm{H} 28 \backslash \mathrm{E})=\frac{0.27 * 0.6}{0.56}=0.28 \\
& \mathrm{~K}(\mathrm{H} 29 \backslash \mathrm{E})=\frac{0.18 * 0.4}{0.56}=0.12
\end{aligned}
$$

4. Langkah selanjutnya mencari nilai bayes dari metode Teorema bayes dengan suatu cara mengalikan nilai probabilitas evidence awal atau $\mathrm{K}\left(\mathrm{E} \mid \mathrm{H}_{\mathrm{i}}\right)$ dengan nilai hipotesa $\mathrm{H}_{\mathrm{i}}$ benar jika diberikan evidence $\mathrm{E}$ atau $\mathrm{K}\left(\mathrm{H}_{\mathrm{i}} \mid \mathrm{E}\right)$ dan menjumlahkan perkalian.

a. $\mathrm{K} 01=$ Bluetooth

$$
\sum_{k=0}^{n} \text { bayes }=K\left(E \mid H_{\mathrm{i}}\right) * K\left(H_{\mathrm{i}} \mid E_{\mathrm{i}}\right) \ldots+K\left(E \mid H_{\mathrm{i}}\right) * K\left(H_{\mathrm{i}} \mid E_{\mathrm{i}}\right)
$$

$$
\sum_{k=2}^{2}=(0.5 * 1)
$$

b. $\mathrm{K} 02=$ Memori

$$
\sum_{k=2}^{2}=(0.6 * 1)
$$

c. $\mathrm{K} 03=\mathrm{Keypad}$

$$
\sum_{k=2}^{2}=(0.6 * 1)
$$


$=0.60$

$$
\sum_{\substack{k=2 \\=0.33}}^{2}=(0.33 * 1)
$$

e. $\mathrm{K} 05=\mathrm{IC}$ Power

$$
\sum_{k=4}^{4}=(0.42 * 0.34)+(0.58 * 0.65)
$$

f. $\mathrm{K} 06=\mathrm{LCD}$

$$
\sum_{\substack{k=2 \\=0.55}}^{2}(0.6 * 0.28)+(0.6 * 0.28)+(0.6 * 0.28)+(0.4 * 0.12)
$$

\section{Penetapan Kesimpulan}

Dari hasil perhitungan menggunakan metode Teorema Bayes diatas, maka dapat di ketahui bahwa diagnosa kerusakan hanphone adalah Keypad dengan nilai kepastian 0.60 atau $60 \%$, Pertama, masuk pada menu "Setting", kemudian pilih "Aplikasi". Lalu cari aplikasi keyboard yang anda gunakan misalnya "Keyboard Android", Kemudian "Hapus Data" dan " Hapus Cache" aplikasi keybard tersebut.

\section{DAFTAR PUSTAKA}

[1] Proceedings of Conference on Information Technology and Electrical Engineering. 2014.

[2] “No Title复杂产品数字样机多性能耦合分析与仿真的若干关键技术研究 及其应用,” pp. 1-5.

[3] A. L. B. Masalah, “BAB I PENDAHULUAN,” pp. 1-15, 2007.

[4] P. Teknik, I. Dan, F. Teknik, and U. N. Semarang, "HANDPHONE DENGAN METODE FORWARD," 2015.

[5] P. S. Ramadhan, "SISTEM PAKAR PENDIAGNOSAAN DERMATITIS IMUN MENGGUNAKAN TEOREMA BAYES," no. 73, pp. 43-48.

[6] M. Pangkey, V. Poekoel, and O. Lantang, "Sistem Pakar Pendeteksi Kerusakan Handphone Berbasis Android," J. Tek. Inform., vol. 8, no. 1, 2016, doi: 10.35793/jti.8.1.2016.12825.

[7] B. Yuwono, "Pengembangan Sistem Pakar Pada Perangkat Mobile Untuk Mendiagnosa Penyakit Gigi," Semin. Nas. Inform., vol. 1, no. semnasIF, pp. 42-50, 2010, doi: 10.1080/13554794.2010.509318.

[8] H. Listiyono, "Merancang dan Membuat Sistem Pakar," J. Teknol. Inf. Din., vol. XIII, no. 2, pp. 115-124, 2008.

[9] T. A. Rahman, Fakhrul; Mandala, Eka Praja Wiyata; Putra, "Perancangan Aplikasi Sistem Pakar Dengan Menggunakan Metode Certainty Factor Untuk Menentukan Jenis Gangguan Disleksia Berbasis Web," J. INKOFAR, vol. 1, no. 1, pp. 12-17, 2017, [Online]. Available: http://www.politeknikmeta.ac.id/meta/ojs/index.php/inkofar/article/view/4.

[10] M. Kurniasih and T. Rismawan, "Epidemiologi Penyakit Tropis," vol. 05, no. 3, 2017.

[11] K. Ramanda, "Penerapan Sistem Pakar Untuk Mendiagnosa Penyakit Pada Kehamilan," None, vol. 11, no. 2, pp. 179-185, 2015, doi: 10.33480/pilar.v11i2.151.

[12] H. T. SIHOTANG, "Sistem Pakar Untuk Mendiagnosa Penyakit Pada Tanaman Jagung Dengan Metode Bayes," vol. 3, no. 1, 2019, doi: 10.31227/osf.io/dguhb.

[13] M. Dahria, "Pengembangan Sistem Pakar Dalam Membangun Suatu Aplikasi," J. Saintikom, vol. 10, no. 3, pp. 199-205, 2011.

[14] A. Fadli, "Sistem Pakar Dasar," pp. 1-8, 2010.

[15] I. P. W. Putra, "Implementasi Teorema Bayes Untuk Menganalisa Kerusakan Pada Air Conditioner Ruangan Berbasis Android,” no. 1, pp. 6-7, 2016. 
[16] D. A. S. Agustina, "Perancangan Aplikasi Computer Based Test (Cbt) Berbasis Web (Studi Kasus Di Smp Negeri 2 Kuta - Badung)," J. Teknol. Inf. dan Komput., vol. 2, no. 1, 2017, doi: 10.36002/jutik.v2i1.223.

[17] S. Santoso and R. Nurmalina, "Perencanaan dan Pengembangan Aplikasi Absensi Mahasiswa Menggunakan Smart Card Guna Pengembangan Kampus Cerdas (Studi Kasus Politeknik Negeri Tanah Laut)," J. Integr., vol. 9, no. 1, pp. 84-91, 2017.

[18] A. Hendini, "No Title," vol. IV, no. 2, pp. 107-116, 2016.

[19] Y. Y. Nanda Amalia, "Rancang Bangun Sistem Pakar Identifikasi Penyakit Fisik Akibat Kerja Dengan Metode Certainty Factor," Manaj. Inform., vol. 4, no. Sistem Pakar, pp. 11-18, 2015.

[20] N. Amalia et al., “Aplikasi Identifikasi Penyakit Fisik Akibat Kerja,” pp. 11-18. 